\title{
SISTEM PENDUKUNG KEPUTUSAN PEMILIHAN BAYI SEHAT
}

\author{
Yulia Jihan Sy ${ }^{1}$, Widya Marna ${ }^{2}$ \\ ${ }^{1,2}$ Dosen Amik Boekittinggi \\ ${ }^{1}$ Email : Syahila02012015@gmail.com \\ Submitted: 16-03-2017, Reviewed: 17 -03- 2017, Accepted 18-03-2017 \\ http://dx.doi.org/10.22202/jei.2017.v3i2.1388
}

\begin{abstract}
Research support healthy infants selection decision at Army Hospital TK IV Bukittinggi in order to design decision support applications election of healthy infants at Army Hospital TK IV Bukittinggi where the electoral process is a long healthy baby is still done manually. The method used in the development of this application is the Iteration methodology includes four phases namely planning stage consists of observation, interviews, library research. The analysis stage composed of DFD, process specifications, process analysis, analysis of output, input analysis, data analysis and requirements analysis. Design stage data flow diagram (DFD), Entity relationship diagram (ERD) and flowchart (flowchart) and implementation. The conclusion that can be drawn by the authors is with their application decision support healthy babies this election, then the process pemelihan healthy infants do better for the future.
\end{abstract}

Keywords : Decision Support Systems; Healthy Babies Election; Visual Basic 2008 and MySQL

\section{PENDAHULUAN}

Perkembangan keberadaan dan kebutuhan akan teknologi sangat berpengaruh terhadap perkembangan masyarakat maupun instansi. Pemanfaatan komputer sebagai alat bantu tidak diragukan lagi. Baik sebagai media penerima data, pengolahan data dan penyimpanan data. Sistem pendukung keputusan dirancang untuk mendukung seluruh tahapan pengambilan keputusan mulai dari mengidentifikasi masalah, memilih data yang relevan, dan menentukan pendekatan yang digunakan dalam proses pengambilan misalnya dalam hal memberikan hasil atau keputusan yang diambil agar dapat dipertanggung jawabkan.

Salah satu contohnya adalah pemilihan bayi sehat. Yang menjadi persoalan dalam penyelenggaraan pemilihan bayi sehat di Rumah Sakit Tentara Tk IV Bukittinggi adalah petugas masih kesulitan dalam menentukan siapa bayi sehat yang terpilihkarena banyaknya kriteria yang harus dipenuhi sehingga memerlukan waktu yang cukup lama dan juga rumit. Untuk itu perlu diciptakan suatu sistem yang lebihefektif dan efisien sehingga penyelenggaraan dan hasil pemilihan bayi sehat dapat dipertanggung jawabkan Selama ini proses pemilihan bayi sehat hanya dilakukan secara manual, karena keterbatasan waktu dan banyaknya kriteria yang harus dipenuhi sehingga petugas Rumah Sakit kesulitan dalam menentukan pemilihan bayi sehat tersebut. Akhirnya proses pemilihan hanya dipilih secara langsung. Hal ini mengakibatkan obyektivitas pemilihan bayi sehat kurang bisa dipertanggung jawabkan hasilnya. Untuk bisa pengadakan pemilihan bayi sehat secara maksimal perlu adanya sistem pendukung keputusan pemilihan bayi sehat sehingga bisa membantu petugas Rumah Sakit dalam menentukan siapa bayi sehat yang terpilih.

Berdasarkan uraian pada latar belakang penelitian, maka yang menjadi permasalahan adalah sebagai berikut :

1. Apa kendala yang sering terjadi jika sistem yang berjalan belum sesuai dengan kebutuhan dalam menggunakan sistem komputerisasi ?

2. Bagaimana merancang dan membuat Sistem Pendukung Keputusan Pemilihan Bayi Sehat di Rumah Sakit Tentara Tk IV Bukittinggi sesuai dengan kriteria yang di tetapkan.

3. Bagaimana implementasi sistem pendukung keputusan pemilihan bayi sehat di Rumah Sakit Tentara Tk IV Bukittinggi? 


\section{METODE PENELITIAN}

\section{A. Metode Analisa}

Dalam pembahasan dan penganalisaan penelitian ini, penulis menggunakan metode analisa kualitatif, yaitu metode yang digunakan untuk mengetahui data dalam bentuk uraianuraian. Metode analisis ini menggunakan data yang berbentuk keterangan yang diperoleh responden secara langsung, tepatnya menggunakan metode analisa deskriptif. Merupakan metode analisis yang bertujuan mendeskripsikan atau menjelaskan sesuatu hal apa adanya.

Penelitian tugas akhir ini merupakan penelitian terapan yang menghasilkan sebuah modul program aplikasi yang dapat digunakan untuk menunjang kegiatan Sistem Pendukung Keputusan Pemilihan Bayi Sehat di Rumah Sakit Tentara TK IV - Adapun metodologi yang dipedomani adalah System Development Life Cycle $(S D L C)$ atau siklus hidup pengembangan sistem. Berikut penjabaran kegiatan selama dilakukan penelitian sesuai tahapan SDLC:

\section{Identification and Selection}

Pada fase ini adalah awal dari kegiatan penelitian dimana dilakukan peninjauan langsung ke lokasi penelitian yaitu Rumah Sakit Tentara TK IV. Adapun kegiatan pada fase ini adalah mengamati pelaksanaan Sistem Informasi pemilihan bayi sehat. Hasil pengamatan tersebut selanjutnya di analisa baik dari sisi kelebihan / Strength (S), kelemahan / Weaknesses $(W)$, peluang / Opportunity $(O)$, maupun ancaman / Threath (T) yang mungkin ada.

Setelah terindentifikasi analisa SWOT, maka peneliti menyerahkan kepada pihak pimpinan untuk dipilih / Selection atau ditetapkan proyek pengembangan yang biasa dilakukan. Artinya hasil seleksi atau penetapan oleh pimpinan tersebut merupakan topik utama dari penelitianm tugas akhir ini.

\section{Initiation and Planning}

Setelah terpilih sebuah proyek pengembangan SI pada fase pertama, maka selanjutnya kegiatan terfokus pada kegiatan SI yang terpilih yaitu hanya terkait pada laporan saja. Dengan demikian kegiatan awalnya adalah dengan mulai menganalisa bentuk-bentuk laporan yang diperlukan, jenis data yang harus dikumpulkan, dan prosedur kerja yang sebaiknya dilakukan. Berdasarkan hasil analisa yang terperinci tersebut, maka disusun rencana untuk meningkatkan penerapan komputer lebih optimis untuk menunjang kegiatan pemilihan bayi sehat .

\section{Analysis}

Di dalam tahap ini terdapat langkahlangkah dasar yang harus dilakukan oleh system analisis, yaitu :

\section{a. Requirement Determination}

Sub ini merupakan kelanjutan dari fase kedua yaitu mendatangi kembali Rumah Sakit Tentara TK IV untuk mendapatkan informasi lebih terperinci lagi. Mengenai kegiatan SI, system pelaporan, jenis data, prosedur kerja dan alat yang digunakan. Sehingga untuk melaksanakan fase ini diperlukan wawancara dan diskusi langsung dengan banyak personal terutama personal yang akan menggunakan program aplikasi ini.

b. Requirement Structuring

Setelah dilaukan determinasi terhadap semua persyaratan SI baru melalui wawancara dan pemantauan langsung maka selanjutnya dilakukan stukturisasi. Yaitu dengan membuat model $U M L$ seperti Use Case Diagram, Activity Diagram, Class Diagram, Sequence Diagram, dan Deployment Diagram. Model grafis yang dihasilkan untuk selanjutnya menjadi pedoman didalam merancang SI baru berbasis komputer lebih optimal.

c. Alternatife Generating Design

Ada 3 kategori untuk mengajukan sejumlah rancangan alternative kepada calon pengguna yaitu kategori Low-end yaitu pengembangan SPK tidak jauh berbeda dengan SPK yang sedang berjalan, hanya memperbaiki beberapa aspek kegiatan kearah yang lebih efektif. Kategori kedua adalah middleend dimana usulan pengembangan lebih meluas dan telah mengandung usulan perubahan teknologi yang digunakan..dan yang ketiga adalah highend, yaitu usulan pengembangan adalah lebih meningkatkan kecanggihan SI 
yang ada sehingga berbasis komputer secara optimal pada semua aspek kegiatan.

\section{Logical Design}

Fase ini dilakukan penyusunan logika yang mendasari program aplikasi yang dibangun yaitu dengan menjabarkan flowchart maupun organisasi database yang diperlukan.

\section{Physical Design}

Fase ini merupakan kelanjutan dari fase ke4 yaitu dengan mengkonversi atau menterjemahkan rancangan logika yang telah terbentuk kedalam bahasa pemograman yang ditetapkan atau disebut juga dengan proses coding.

6. Implementation

Fase ini dilakukan implementasi terhadap modul program aplikasi yang telah dibangun. Yaitu mulai dari menginstal Sistem operasi windows yang sesuai, program aplikasi untuk SPK pemilihan bayi sehat yang menggunakan bahasa pemograman berbasis objek.

\section{Maintenance}

Merupakan fase pemeliharaan system yaitu kegiatan kemungkinan melakukan pemutakhiran (update) data, mengganti sistem database, maupun mengkonversi kebahasa pemrograman terbaru suatu saat nanti.

\section{HASIL PENELITIAN \\ PEMBAHASAN}

DAN

\section{A. Analisa sistem yang sedang berjalan}

Tahap analisa sistem dilakukan sebelum tahap perancangan sistem, tahap analisa sistem merupakan tahap yang penting dalam perancangan suatu sistem, tujuan analisa terhadap sistem yang lama ini adalah untuk mendapatkan suatu hasil yang lebih baik dengan melihat beberapa kelemahan dan kekurangan dari sistem yang lama tersebut.

Permasalahan-permasalahan yang ditemukan pada analisa sistem dapat diatasi dengan mengadakan perubahan-perubahan dengan cara merancang suatu sistem baru, dimana sistem baru tersebut merupakan perbaikan dari sistem lama yang tujuannya dapat menutupi kelemahan-kelemahan yang terdapat pada sistem lama.

\section{Aliran sistem informasi lama}

Aliran sistem informasi merupakan gambaran terhadap suatu informasi dari suatu bagian kebagian lainnya dimana informasi dihasilkan dan diproses pada bagian yang bersangkutan. Untuk jelasnya aliran sistem informasi seleksi bayi sehat yang terdapat pada Rumah Sakit Tentara dapat dilihat pada gambar sebagai berikut:

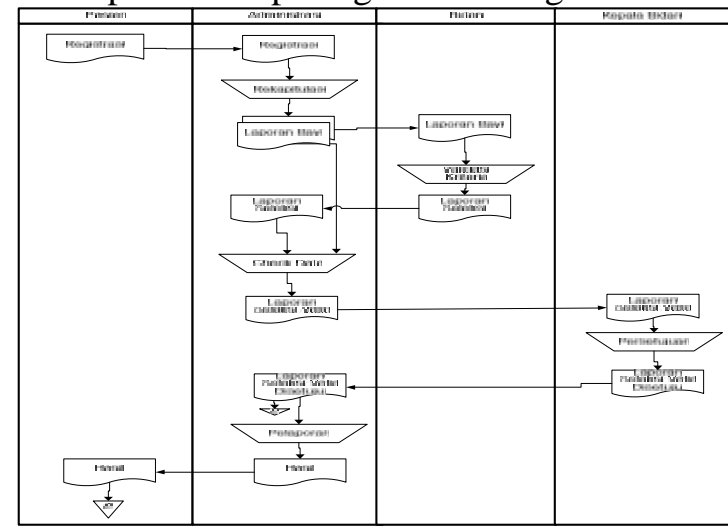

Gambar 3.1 Aliran Sistem Informasi lama

\section{Perancangan Sistem}

1. Aliran Sistem Informasi Yang Akan Dikembangkan

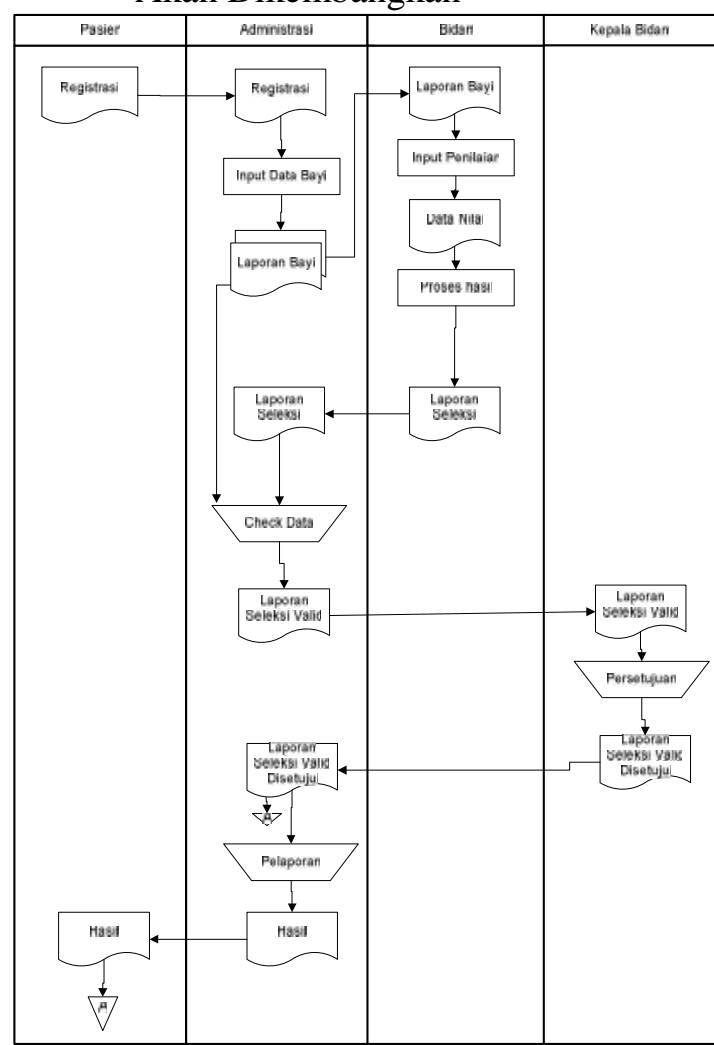

Gambar 3.2 Aliran Sistem Informasi Baru

2. Context Diagram

Context Diagram adalah rancangan yang menggambarkan gambaran umum terhadap arus data dan informasi antara sistem dan entity 
lainnya. Context Diagram tersebut dapat dilihat pada gambar 23 berikut :

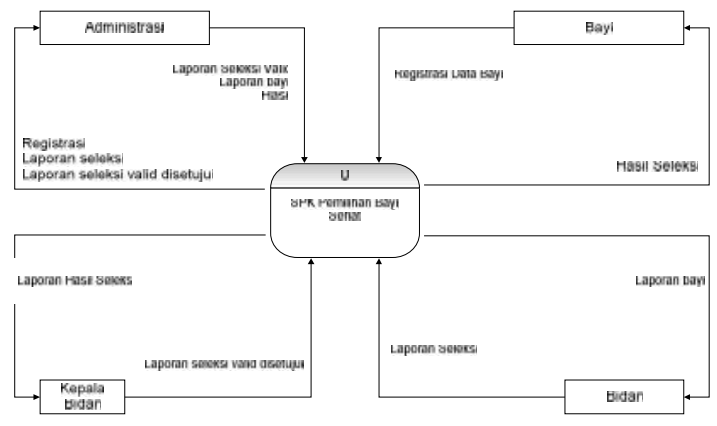

Gambar 3.3 Context Diagram

3. Data Flow Diagram (DFD)

Data Flow Diagram (DFD) sering digunakan untuk menggambarkan suatu sistem yang telah ada atau sistem baru yang akan dikembangkan secara logika tanpa mempertimbangkan lingkungan fisik dimana data tersebut mengalir atau lingkungan fisik dimana data tersebut akan disimpan (misalnya di hardisk, disket dan lain sebagainya).

Untuk lebih merinci mengenai rancangan sistem baru perlu di jabarkan sebuah Data Flow Diagram (DFD) yang merupakan penguraian dari proses utama yang tertera pada Context Diagram.

Dengan mengacu pada context diagram yang ada, maka untuk dapat memperjelas proses yang terjadi adalah dengan menguraikan proses tersebut kedalam DFD yang dapat dilihat pada gambar 24 sebagai berikut:

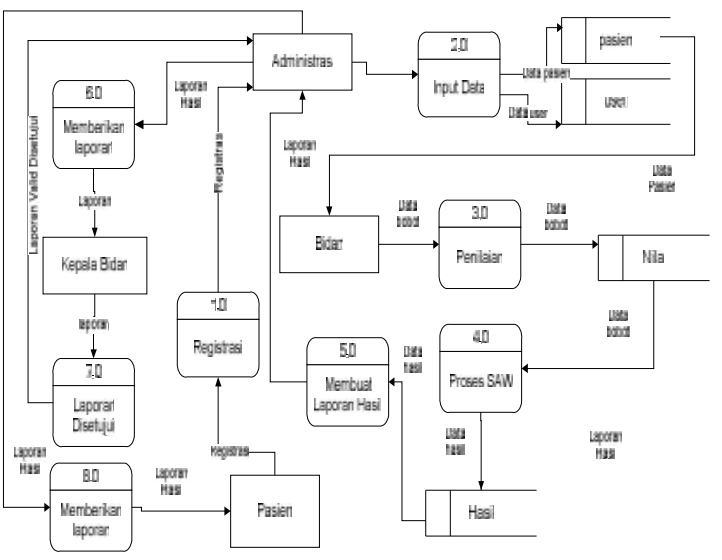

Gambar 3.4 Data Flow Diagram

\section{Relasi Antar Tabel}

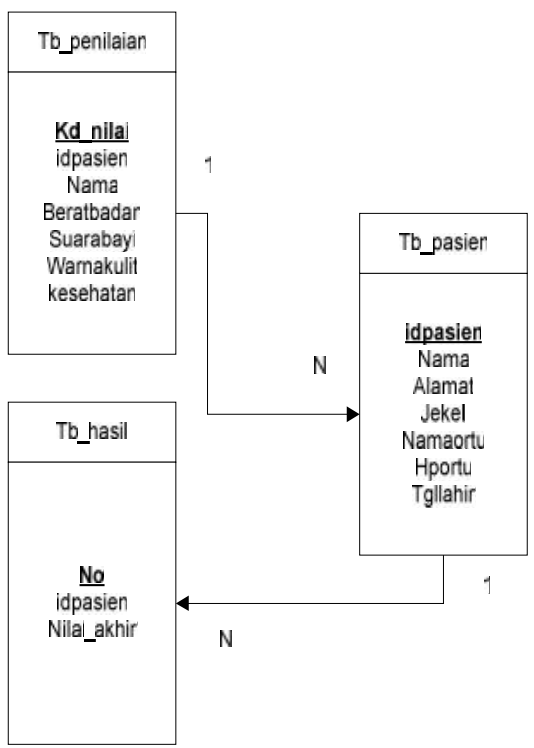

Gambar 3.5 Relasi Antar Tabel

3. Desain Database

a. Pada sistem informasi File Tabel Bobot

Nama Database: dbbayi

Nama Tabel : tb_Bobot

Primary Key : No

Tabel 3.1 Tabel Kriteria

\begin{tabular}{|c|c|c|}
\hline Nama Ficld & Typc & Ket \\
\hline$\underline{\underline{N} 0}$ & int(11) & Nomor Urut \\
\hline Bcratbadan & Float & Bobot Berat \\
\hline Suarabayi & Float & Bobot Suara Bayi \\
\hline Warnakulit & Float & Bobot Warna \\
\hline kesehatan & Float & BobotKesehatan \\
\hline
\end{tabular}

b. File Penilaian

Nama Database : dbbayi

Nama Tabel

: tb_Penilaian

Primaty Key

: kd_nilai

Tabel 3.2 Tabel Penilaian

\begin{tabular}{l|l|l}
\hline \multicolumn{1}{c}{ Nama Fleld } & \multicolumn{1}{|c}{ Type } & \multicolumn{1}{c}{ Ket } \\
\hline Kd nilai & Int(11) & KodeNilai \\
\hline idpasien & varchar(20) & Kode pasien \\
\hline Nama & varchar(35) & Nama Produk \\
herathadan & Float & Nilai Rerat Radan \\
\hline warnakulit & Float & Nilai Warna Kulit \\
\hline suarabayi & Float & Nilai Suara \\
\hline Kesehatan & Float & Nilai Kesehatan
\end{tabular}

c. File Program

Nama Database : dbbayi

Nama Tabel

: tb_pasien

Primary key
: idpasien 
Penelitian Bidang Komputer Sains dan Pendidikan Informatika V3.i2(88-94)

Tabel 3.3 Tabel Pasien

\begin{tabular}{|c|c|c|}
\hline Nama Ficld & Туре & $\mathrm{Ket}$ \\
\hline Tdpasien & varchar $(20)$ & KodePasien \\
\hline Nama & varchar $(35)$ & Nama Pasicn \\
\hline Igliahir & Date & Tanegal lahir \\
\hline $\begin{array}{l}\text { Nemu Orlu } \\
\text { Alamat }\end{array}$ & $\begin{array}{l}\text { velucher(35) } \\
\text { varchar(22.5) }\end{array}$ & $\begin{array}{l}\text { Namu Oraigy Tua } \\
\text { Alamat oranf, tha }\end{array}$ \\
\hline Hportu & $\operatorname{varchar}(35)$ & Kontak Orang Tua \\
\hline Jekel & varchar(35) & Jenis Keliamin \\
\hline
\end{tabular}

d. File Rangking

Nama Database : dbbayi

Nama Tabel

Primary key

: tb_hasil

: no

Tabel 4 Tabel Ranking

\begin{tabular}{l|l|l}
\hline Nama Field & \multicolumn{1}{|c|}{ Type } & \multicolumn{1}{c}{ Ket } \\
\hline No & int(11) & Rangking \\
\hline Idapasien & varchar(30) & KodePasien \\
\hline NilaiAkhir & Float & -ilaiHasil \\
\hline
\end{tabular}

e. File User

Nama Database : dbbayi

$\begin{array}{ll}\text { Nama Tabel } & \text { : tb_user } \\ \text { Primary key } & \text { : username }\end{array}$

Tabel 5 Tabel User

\begin{tabular}{ll|l|}
\hline Nama Field & \multicolumn{1}{c|}{ Type } & \multicolumn{1}{c|}{ Ket } \\
\hline username & varchar $(20)$ & Kodeuser \\
\hline password & varchar $(60)$ & Password \\
\hline
\end{tabular}

4. Desain Input

Desain input merupakan suatu alat masukan data yang dibutuhkan dalam proses pembuatan output atau laporan. Adapun bentuk rancangan input tersebut adalah :

a. Desain Input Proses

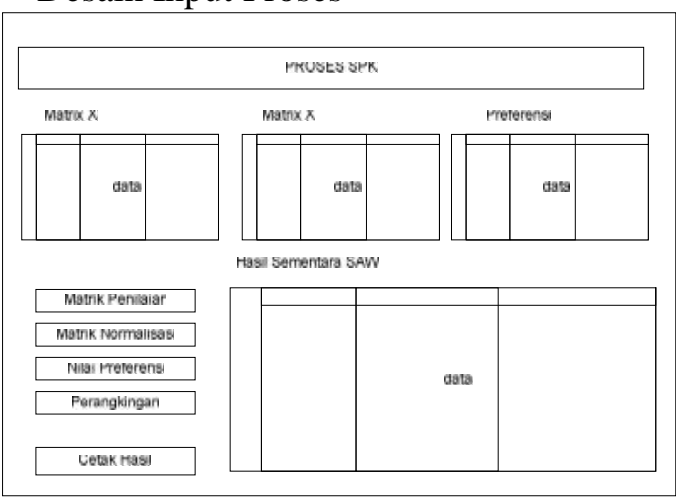

Gambar 3.6 Desain input proses b. Desain Input Detail Program

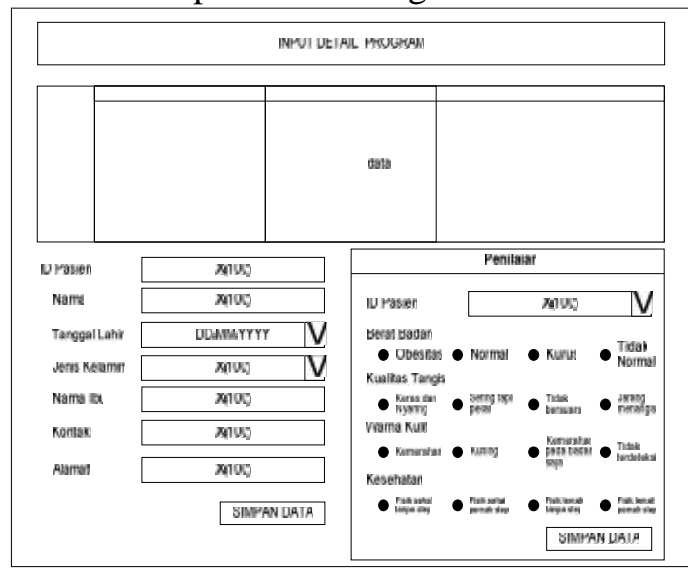

Gambar 3.7 Desain Input detail program

c. Desain Input Bobot

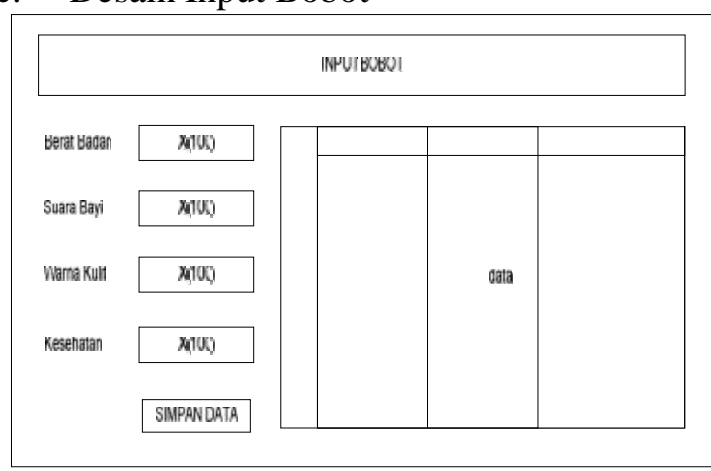

Gambar 3.8 Desain input bobot

d. Desain Input Login

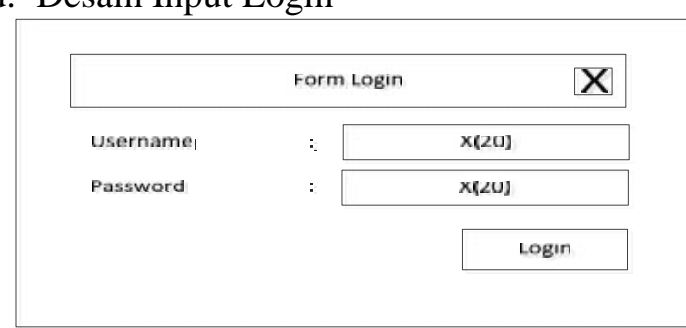

Gambar 3.9 Desain Input login

\section{Desain Output}

Suatu sistem yang baik adalah yang dapat menghasilkan keluaran yang mudah dipahami, terinci dan bebas dari kesalahan-kesalahan perhitungan serta dapat memberikan hasil sesuai dengan yang diharapkan, fungsi dari desain output salah satunya adalah suatu rancangan yang digunakan untuk melihat hasil dari proses yang telah dilaksanakan. Berdasarkan kebutuhan yang ada, maka dirancang beberapa bentuk laporan yang akan diberikan kepada pimpinan dalam langkah 
pengambilan keputusan dan kebijakan. Adapun bentuk desain output program ini adalah sebagai berikut :

a. Laporan Hasil Seleksi

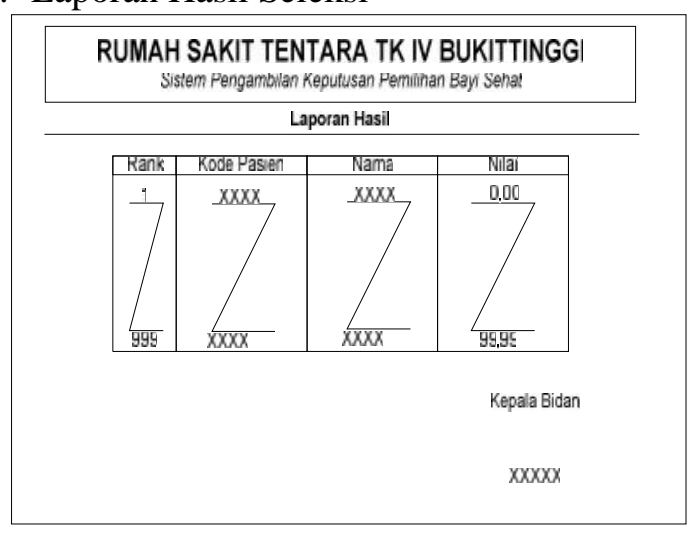

Gambar 3.10 Laporan Hasil Seleksi

b. Laporan Detail Hasil Seleksi

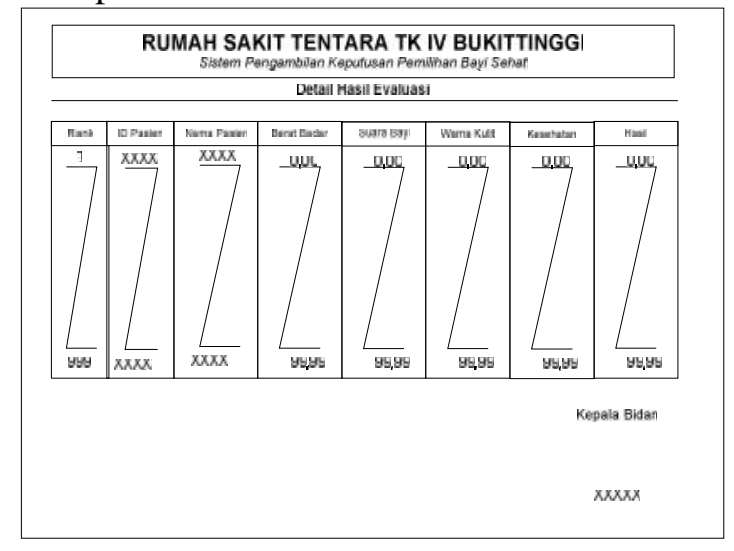

Gambar 3.11 Laporan Detail Hasil Seleksi

\section{Perhitungan SAW}

Perhitungan SAW merupakan perhitungan yang akan kita gunakan dalam mengambil keputusan untuk menentukan pemilihan bayi sehat. Adapun simulasi perhitungannya sebagai berikut :

$\mathrm{C} 1=$ Berat Badan

$\mathrm{C} 2=$ Warna Kulit

C3 = Suara Bayi

$\mathrm{C} 4=$ Kesehatan

Pengambilan keputusan memberikan bobot untuk kriteria sebagai berikut : $\mathrm{C} 1=35 \% ; \mathrm{C} 2=25 \% ; \mathrm{C} 3=25 \% ; \mathrm{C} 4=15 \%$

Ada 4 orang anak yang akan menjadi alternative untuk pemilihan bayi sehat, yaitu : A1 = Najla A2 = Alya
A3 = Syaqira

A4 = Khanza

Tabel 3.6 Tabel nilai alternatif setiap kriteria

\begin{tabular}{|l|c|c|c|c|}
\hline \multirow{2}{*}{ Alternatif } & \multicolumn{4}{|c|}{ Kriteria } \\
\cline { 2 - 5 } & $\mathrm{C} 1$ & $\mathrm{C} 2$ & $\mathrm{C} 3$ & $\mathrm{C} 4$ \\
\hline Najla & 70 & 50 & 80 & 60 \\
\hline Alya & 50 & 60 & 82 & 70 \\
\hline Syaqira & 85 & 55 & 80 & 75 \\
\hline Khanza & 82 & 70 & 65 & 85 \\
\hline
\end{tabular}

Membuat matriks keputusan $\mathrm{X}$ berdasarkan kriteria, kemudian melakukan normaliasi matriks berdasarkan persamaan yang disesuaikan jenis atribut sehingga diperoleh matriks ternormalisasi R.

$$
\begin{aligned}
& r_{11}=\frac{70}{\max \{70 ; 50 ; 85 ; 82\}}=\frac{70}{85}=0,82 \\
& r_{12}=\frac{50}{\max \{50 ; 60 ; 55 ; 70\}}=\frac{50}{70}=0,71 \\
& r_{13}=\frac{80}{\max \{80 ; 82 ; 80 ; 65\}}=\frac{80}{80}=1 \\
& r_{14}=\frac{60}{\max \{60 ; 70 ; 75 ; 85\}}=\frac{60}{85}=0,70 \\
& r_{21}=\frac{50}{\max \{70 ; 50 ; 85 ; 82\}}=\frac{50}{85}=0,58 \\
& r_{22}=\frac{60}{\max \{50 ; 60 ; 55 ; 70\}}=\frac{60}{70}=0,85 \\
& r_{23}=\frac{82}{\max \{80 ; 82 ; 80 ; 65\}}=\frac{82}{80}=1,02 \\
& r_{24}=\frac{70}{\max \{60 ; 70 ; 75 ; 85\}}=\frac{70}{85}=0,82 \\
& r_{31}=\frac{85}{\max \{70 ; 50 ; 85 ; 82\}}=\frac{85}{85}=1 \\
& r_{32}=\frac{55}{\max \{50 ; 60 ; 55 ; 70\}}=\frac{55}{70}=0,78 \\
& r_{33}=\frac{80}{\max \{80 ; 82 ; 80 ; 65\}}=\frac{80}{80}=1 \\
& r_{43}=\frac{75}{\max \{80 ; 82 ; 80 ; 65\}}=\frac{85}{\max \{60 ; 70 ; 75 ; 85\}}=\frac{85}{85}=1 \\
& r_{42}=\frac{70}{\max \{60 ; 70 ; 75 ; 85\}}=\frac{75}{85}=0,88 \\
& r_{41}=\frac{82}{\max \{70 ; 50 ; 85 ; 82\}}=0,96 \\
& r_{42}
\end{aligned}
$$

Hasil normalisasi :

\section{Diterbitkan Oleh Program Studi Pendidikan Informatika STKIP PGRI Sumbar}


Penelitian Bidang Komputer Sains dan Pendidikan Informatika V3.i2(88-94)

$$
\mathrm{R}=\left[\begin{array}{cccc}
0,82 & 0,71 & \mathbf{1} & 0,70 \\
0,58 & 0,85 & 1,02 & 0,82 \\
1 & 0,78 & 1 & 0,88 \\
0,96 & 1 & 0,81 & 1
\end{array}\right]
$$

Hasil akhir diperoleh dari proses perankingan yaitu penjumlahan dari perkalian matriks ternormalisasi $\mathrm{R}$ dengan vector bobot sehingga diperoleh nilai terbesar yang dipilih sebagai alternatif terbaik sebagai solusi.

Proses perankingan menggunakan bobot yang telah diberikan oleh pengambil keputusan: $\mathrm{W}=\left[\begin{array}{llll}0,35 & 0,25 & 0,25 & 0,15\end{array}\right]$

Hasil yang diperoleh sebagai berikut :

$V_{1}=\left(0,35^{*} 0,82\right)+\left(0,25^{*} 0,71\right)+\left(0,25^{*} 1\right)+$ $(0,15 * 0,70)=0,819$

$V_{2}=\left(0,35^{*} 0,58\right)+\left(0,25^{*} 0,85\right)+\left(0,25^{*} 1,02\right)+$ $\left(0,15^{*} 0,82\right)=0,793$

$V_{3}=\left(0,35^{*} 1\right)+\quad\left(0,25^{*} 0,78\right)+\left(\quad 0,25^{*} 1\right)+$ $\left(0,15^{*} 0,88\right)=0,927$

$V_{4}=(0,35 * 0,96)+\quad(0,25 * 1)+(\quad 0,25 * 0,81)+$ $\left(0,15^{*} 1\right)=0,938$

Jadi menurut perhitungan diatas hasil pemilihan bayi sehat dapat dilihat dari tabel dibawah ini :

\section{Tabel 3.7 Tabel peringkat pembobotan} bayi sehat

\begin{tabular}{|c|c|c|}
\hline Nama & Scor & Ranking \\
\hline Najla & 0,819 & 3 \\
\hline Alya & 0,793 & 4 \\
\hline Syaqira & 0,927 & 2 \\
\hline Khanza & 0,938 & 1 \\
\hline
\end{tabular}

Nilai terbesar ada pada Khanza, sehingga aalternatif yang terpilih sebagai alternative terbaik dengan kata lain, Khanza terpilih menjadi bayi paling sehat.

\section{SIMPULAN}

Dari berbagai penjelasan yang telah diuraikan dalam laporan ini, maka dapat disimpulkan hal-hal sebagai berikut.

1. Dengan dibangunnya Aplikasi Sistem Pendukung Keputusan ini diharapkan adanya peningkatan pelayanan terhadap pasien.

2. Dengan pemanfaatan Aplikasi Sistem Pendukung Keputusanini diharapkan perawat dan bidan dapat dengan mudah, cepat dan akurat dalam memilih bayi sehat.
3. Dengan adanya Sistem Pendukung Keputusan pemilihan bayi sehat diharapkan dapat mempermudah proses pemilihan bayi sehat, pemberian informasi kepada pasien serta merancang bentuk laporan yang lebih menarik serta lebih efektif dan informatif.

\section{DAFTAR PUSTAKA}

Akbar, Dafid Muhammad. 2015. Perancangan Sistem Pendukung Keputusan Verivikasi Kelayakan Calon Tenaga Kerja Indonesia (CTKI) dengan Metode Simple Additive Weighting (SAW). Jatisi. 2: 14.

Djamain, Yasni., Christin, Herlinda De. 2015. Sistem pendukung keputusan penerimaan pegawai baru pt.pln (persero) kantor pusat dengan menggunakan metode simple additive weighting (saw). Teknik Informatika. 8 (1): 39-47.

Eniyati,

Sri.

2011.

Perancangan Sistem Pendukung Penga mbilan Keputusan untuk Penerimaan Beasiswa dengan Metode SAW (Simple Additive Weighting). Dinamik-Jurnal Teknologi Informasi. 16: 171-177.

Hermanto, Nandang. 2012. Sistem Pendukung Keputusan Menggunakan Metode Simple Additive Weighting (Saw) Untuk Menentukan Jurusan Pada Smk Bakti Purwokerto. Seminar Nasional Teknologi Informasi \& Komunikasi Terapan 2012. 2012: 52-62.

Kamaludin, Asep. 2012. Sistem Pendukung Keputusan Dalam Pemilihan Alternatif Alat Kontrasepsi Menggunakan Simple Additive Weighting. UIN Bandung: 15.

Jaya, Tri Sandhika. 2012. Sistem Pemilihan Perumahan Dengan Metode Kombinasi Fuzzy C-Means Clustering Dan Simple Additive Weighting. Jurnal Sistem Informasi Bisnis. 3: 153-158. 